\title{
Did The Pension Protection Act (PPA) Of 2006 Resolve The Pension Crisis In Corporate America?
}

\author{
John J. Lucas, Purdue University Calumet, USA
}

\begin{abstract}
On August 17, 2006, President George W. Bush signed into law the Pension Protection Act (PL 109-280). The 907-page federal law has been referred to as the most comprehensive reform of the nation's pension law since the enactment of the Employee Retirement Income Security Act (ERISA) of 1974 (Lucas, 2008). This paper will examine the major provisions of the Pension Protection Act (PPA). Additionally, the paper will analyze the impact of PPA on the retirement programs in corporate America and whether it resolved the pension crisis that existed prior to its passage as a federal law.
\end{abstract}

Keywords: Pension Laws; Pension Protection Act

\section{BACKGROUND}

¿ $\mathrm{t}$ has been two years since the $109^{\text {th }}$ Congress passed the Pension Protection Act (PPA) of 2006. The primary objective of this landmark Act was to bolster the traditional defined benefit pension system in corporate America by requiring employers to maintain certain pension funding levels to ensure that the promised pension benefit would be paid to their employees (Hoffman, 2007). In essence, the PPA increased the accountability of employers relating to the defined benefit plans that they offer. Additionally, the Act also contained major provisions that affected defined contribution plans offered by corporate America. An important question that still remains is whether the PPA achieved its goals and ended the pension plan crisis that existed in corporate America.

\section{PENSION PROTECTION ACT (PPA)}

On August 17, 2006, the Pension Protection Act (PPA), known as PL 109-280, was signed into law by President George W. Bush. The PPA consisted of fourteen major Titles ranging from Title I Reform of Funding Rules for Single Employer Benefit Pension Plans to Title XIV Tariffs Provisions. This comprehensive bill established new funding requirements as well as reforms for defined contribution plans and cash balance plans (Purcell, 2006).

Under Title I Section 303, referred to as "Reform Funding Rules for Single-Employer Defined Benefit Pension Plans," new minimum funding requirements were established for the traditional defined benefit plans of a single employer plan. The Act required an ultimate "funding target" of $100 \%$ for single-employer plans, and was to be phased in at $92 \%$ in $2008,94 \%$ in $2009,96 \%$ in 2010, and 100\% in 2011(Purcell, 2006). The funding target requirement was to ensure that the assets of the defined benefit plan covered the plan's liabilities or promised retirement benefits.

Additionally, there were special rules for "at-risk plans." A plan was in at-risk status for a plan year if "the funding target attainment percentage for the proceeding plan year was less than eighty percent" (PL109-280, 2006). A transition rule was established for at-risk plans with 65\% in 2008, 70\% in 2009, and 75\% in 2010 (U.S Public Law 109-280, 2006). For at-risk plans, employers were required to make accelerated quarterly contributions for the 
underfunded plans. The due dates for these quarterly payments were: April 15, July 15, October 15, and January 15 of the following year (U.S. Public Law 109-280, 2006). The Secretary of Treasury was given the responsibility to govern and apply "any regulations as were necessary" for at-risk provisions outlined under the PPA.

Another major provision outlined in the PPA pertained to the reforms for defined contributions plans. These retirement plans established individual accounts to which the employer, employee, or both made periodic contributions (GAO, 2002). A common defined contribution was a 401(k) plan or 403(b) plan for nonprofit-sector employees. A typical 401(k) plan consisted of three major accounts: a pretax account, a post tax account, and an employer matching contribution (Lucas, 2006). An employee was solely given the responsible to invest an array of investment choices into these various accounts, and the amount of retirement benefit was based upon the performance of the selected investments.

Title IX, known as "Increase in Pension Plan Diversification and Participation and Other Pension Provision," outlined various reforms for the defined contribution plans offered by corporate America. One revision was under Section 902 which established automatic contribution arrangements permitting an employer to enroll employees into their $401(\mathrm{k})$ plans. In essence, this section outlined provisions to increase employee participation in 401(k) plans through the action of automatic enrollment by employers. Additionally, an employee was afforded the opportunity to opt out of the 401(k) plan with an "affirmative election to not have such contribution made." Under this provision of the law, a plan participant, who is automatically enrolled in the 401(k) plan, has ninety days to withdraw from the plan (Lucas, 2008).

Still another modification for the defined contribution plan was the establishment of a "safe harbor" from nondiscrimination testing, if certain standards were met. To qualify for the automatic "safe harbor" the contribution rate, by an employer, must be 3\% for the first year; 4\% during the second year; 5\% during the third year; and $6 \%$ during any subsequent plan year. The "qualified percentage" standard for the safe harbor was limited to 10\% (U.S. Public Law 109-280, 2006).

Another major reform relating to defined contribution plans was outlined under Title VI-Subtitle A"Investment Advice." This title amended section 408 (b) entitled "Exemption From Prohibited Transactions" of the Employee Retirement Income Security Act (ERISA) of 1974 (Lucas, 2008). Employers were allowed to provide a "fiduciary adviser" to provide investment advice to employees pertaining to the offered 401(k). The "qualified fiduciary advisor" was a registered investment company, bank, insurance company, or a registered broker-dealer (Purcell, 2006). The fiduciary adviser was permitted to receive compensation in exchange for providing investment advice without a violation of the "prohibited transaction" outlined under ERISA (Lucas, 2008).

Under section (g) of Title VI, the investment recommendations by the qualified fiduciary adviser must be based on a computer model that is certified and audited by a third party (Leonard, 2006). The Secretary of Labor, in consultation with the Secretary of Treasury, was given the responsibility of the feasibility of the investment advice based upon the prescribed computer model. The fiduciary adviser section of the PPA has been deemed as the most controversial since employers were granted the opportunity to provide investment advice, as long as they disclosed a conflict of interest. In essence, "it was a get out of jail free card" associated with the fiduciary responsibilities of 401(k) plans by employers (Kidd Stewart, 2007).

Another significant provision in the PPA was the clarification connected with the so- called cash balance plans. Basically, a cash balance was a type of defined benefit plan where a hypothetical individual account grew by an annual credit established by an employer, and also earned an interest credit (Schultz and Francis, 2006). For example, the employer made a hypothetical contribution of three percent of the employee's salary and the account earned interest credits to the rate of return on a 30-year Treasury bond.

A controversy emerged with the implementation of cash balance plans in corporate America as older workers were impacted when employers converted from a defined benefit plan to a cash balance plan. The conversion resulted in a phenomenon referred to as "wearaway" where older workers needed to earn additional pension benefits in order to reach the previous level of a defined benefit plan (Lucas, 2007). The cash balance controversy climaxed in the Cooper v. The IBM Personal Pension Plan (July 31, 2003) when a U.S. District Court 
ruled that IBM had discriminated against older workers with their cash balance plan (Lucas, 2007).

Under Title VII, "Benefit Accrual Standards" there were "special rules relating to age" established for defined benefit plans which included cash balance plans. Basically, cash balance plans do not ordinarily discriminate against older workers if the benefits were fully vested after three years of service and interest credits were not above the market rate of return (Purcell, 2006). Additionally, this provision included an age discrimination test "comparison to similarly situated younger individual." In essence, if a plan participant's accrued benefit is not less than the accrued benefit of any other employee similarly situated in all respects except age (Purcell, 2006). The law also prohibited wear-away of accrued benefits if the conversion to cash balance plan occurred after June 29 , 2005(Purcell, 2006).

The important provision of the PPA that addressed the underfunded pension funds during bankruptcy was Title IV "PBGC Guarantee and Related Provisions." The primary purpose of this provision was to bolster the 'financially ailing" PBGC. A funding crisis had emerged for the PGBC with several terminations of defined benefit plans, especially within the airline and steel industries (Lucas, 2007). For example, United Airlines (UAL) terminated its pension liabilities signifying the largest default in PBGC history. It was estimated that the UAL pension was underfunded by 9.8 billion and that the PGBC guaranteed approximately $\$ 5$ billion of that amount (www.pbgc.gov, 2007). As a result of numerous defaults, the PGBC had a \$22.8 billion deficit at the end of 2005 (Leonard, 2006).

Title IV of the PPA contained various provisions to address the deficit incurred by the PBGC. The per capita premium of $\$ 30$ as enacted by the Deficit Reduction remained intact under Section 401 "PBGC Premiums." A surcharge of $\$ 1,250$ per participant was assessed for three years against any company that terminated an underfunded pension plan during a Chapter 11 bankruptcy and then emerged from such bankruptcy (Purcell, 2006). Under section 404 "Rules Relating to Bankruptcy of Employer," the termination date of the pension plan for the PBGC purposes was recognized as the date the company filed for Chapter 11 bankruptcy (www.thomas.loc.gov, 2007). Additionally, section 411 of Title IV replaced the term of "Chairman of the Board of Directors" with "Director of PBGC" who was appointed by the President and approved with the consent of the Senate (Public Law 109-280, 2006).

\section{EFFECTIVENESS OF THE PPA}

The PPA was enacted as a federal law to respond to the pension crisis that had emerged in corporate America. Based on this objective of the law, the question that arises is how effective was the PPA regarding its primary goal of bolstering the retirement system in corporate America? Simply stated, did the PPA work?

One primary purpose of the PPA was to bolster the "financially ailing" PBGC. In its Annual Management Report, the PBGC reported a deficit of \$13.1 billion in 2007, as compared to an \$18.1 billion shortfall in 2006 (www.pbgc.gov, 2007). Thus, there was a $\$ 5$ billion improvement in its insurance program for single-employer pension plans. Additionally, there were also no new large pension plans that were deemed as probable losses on the 2007 PBGC balance sheet. The Annual Management Report also indicated that the PBGC's future pension losses from financially weak companies decreased to $\$ 66$ billion in comparison to $\$ 73$ billion in 2006 (www.pbgc.gov, 2007).

Another major goal of the PPA was the automatic enrollment in defined contribution plans such as 401(k) plans. At its recent semi-annual policy forum, the Employee Benefit Research Institute (EBRI) stated that the "automatic 401(k) provision was having a desired effect" in corporate America. In essence, numerous employers, especially large employers, were implementing an automatic enrollment feature in their 401(k) plans. Also, the "auto" provision of the PPA was likely to have a positive impact on workers to save additional monies for their retirement (EBRI News, 2008). Therefore, corporate America was seeking to enhance its 401(k) participation with the use of automatic enrollment for its employees. In a recent survey conducted by Hewitt Associates, thirty six percent of 401(k) plans now offered automatic enrollment which was up from twenty four percent in 2006 (Laise, 2007). 
Still another major provision, within the context of the PPA that impacted the retirement plans in corporate America was the right of an employer to provide investment advice from a fiduciary advisor to their employees. This provision encouraged employers and the financial-service firms that administer the 401(k) plans to provide investment advice to workers in order to navigate thru the various investment choices (Opdyke and Laise, 2006). The investment advice was provided through computer models, such as Guided Choice, Inc. and Financial Engines, Inc. as well as one-on-one advice which was more effective but cost more (Opdyke and Laise, 2006). It remains to be seen how effective and transparent these computer models are in providing investment advice to workers.

\section{CONCLUSION}

This paper analyzed the major provisions of the PPA and also reviewed its impact on the retirement programs in corporate America. The PPA did reduce the deficit of the PBGC's insurance program for singleemployer pension plans by five billion dollars. With automatic enrollment of defined contribution plans, employers have enhanced the participation of their workers. The PPA also permitted employers to provide investment advice to their employees via a fiduciary advisor. It remains to be seen if the investment advice given by a fiduciary advisor is truly transparent and is in the best interest of the plan participants (Lucas, 2008). Recently, in the LaRue v. Dewolff, Boberg, and Associates case (February 20, 2008), the Supreme Court ruled that pension law "does authorize recovery for fiduciary breaches that impair the value of plan assets in a participant's individual account." Potentially, this court ruling could provide the legal groundwork that advisors must give sound investment advice or face legal ramifications.

The PPA did indeed achieve some of its major objectives to resolve the pension crisis in corporate America. However, there are still some fundamental pension plan issues that need to be addressed. Recently, H.R. 5754, referred to as the Employees' Pension Security Act of 2008, has been introduced to the House of Representatives by Congressman Peter J. Visclosky (Dem., IN). Basically, the measure requires failing companies to consider alternatives to pension terminations and the right to challenge court decrees under Chapter 11 bankruptcy. Additionally, the bill also provides single-employer pension plans to have representatives serve as joint trustees on pension boards, and also requires a $\$ 1,000$ a day for a breach of the "fiduciary duty" requirement of providing accurate advice (H.R. 5754, 2008). It will be interesting to see if this congressional bill will be passed in order to resolve some of these pending retirement plan issues in corporate America.

\section{AUTHOR INFORMATION}

John J. Lucas, Purdue University Calumet. Dr. Lucas was formerly the Industrial Relations Representative for Commonwealth Edison. He has experience in all facets of Human Resource Management including labor relations, benefits administration, human resource planning, and health education. He earned his Master of Science in Industrial Relations (MSIR) and Ph.D. degrees from Loyola University Chicago. He is an Associate Professor at Purdue University Calumet and teaches a variety of human resource management courses. His research interests are in the areas of labor relations, employee benefits, and health education. He is also a graduate of Purdue University Calumet.

\section{REFERENCES}

1. Employee Benefit Research Institute News. Speakers Say 'Automatic 401(k)

2. $\quad$ Provisions Are Having Desire Effect. www.ebri.org. Accessed July 18, 2008.

3. Hoffman, Ellen, Deciphering the New Retirement Law. www.ebscohost.com. Accessed September 9, 2007.

4. H.R. 4. www.thomas.loc.gov . Accessed January 24, 2007.

5. Laise, Eleanor, Employers Grab of Workers' 401(k)s, Wall Street Journal, 25 April 2007, Sec D-1 and 9.

6. Leonard, Bill, Congress Passes Landmark Pension Reform Bill, www.shrm.org. Accessed August 11, 2006.

7. Kidd Stewart, Janet, Workers Well-Advised to Question 401(k) Advice, Chicago Tribune 7 April 2007, Sec 5. 
8. Lucas, John J., An Update on 401(k) Plans in the United States, Journal of Business \& Economics Research, Vol. 6, No. 5 May 2008.

9. Lucas John J., The Controversy Surrounding Cash Balance Pension Plans, Journal of the Academy of Business Administration, Vol. 10, No. 1\&2 Spring/Fall 2005.

10. Lucas John J., What is the Future for Defined Benefit Plans in the United States? Journal of Business and Behavioral Sciences, Vol. 15, No 2 Spring 2007.

11. Opdyke Jeff D., and Eleanor Laise, More Employers to Offer Advice on 401(k) Plans, Wall Street Journal, 30 August 2006, Sec D1-2.

12. $\quad$ PBGC Releases Financial Results for Fiscal Year 2007. www.pbgc.org. Accessed September 17, 2008.

13. Purcell, Patrick, H.R.: The Pension Protection Act. CRS Report for Congress, 27 September 2006.

14. Purcell, Patrick, Summary of the Pension Protection Act. CRS Report for Congress, 23 October 2006.

15. Schultz Ellen E. and Theo Francis, What You Need to Know About Pension Changes, Wall Street Journal, 15 August 2006, Sec D1-2.

16. U.S. General Accounting Office. 2002. Answers to Key Questions About Private Pension Plans. Washington, D.C.

17. U.S. House of Representatives H.R. 5754. $110^{\text {th }}$ Congress. 2 sess. 9 April 2008. Employees' Pension Security Act of 2008.

18. U.S. Public Law 109-280. 109th Congress. 17 August 2006. Pension Protection Act of 2006. 
NOTES 